\section{ANNALS OF THE UNIVERSITY OF CRAIOVA}

Series: $\checkmark$ Biology

$\checkmark$ Horticulture

$\checkmark$ Food products processing technology

$\checkmark$ Environmental engineering

\title{
Vol. XXVI (LXII) - 2021 \\ RESEARCH ON THE EFFECTIVENESS OF HERBICIDES IN CONTROLLING THE WEEDS FOR GROWING PEANUTS ON SANDY SOILS IN SOUTHERN OF OLTENIA
}

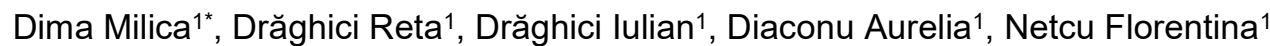 \\ 'Stațiunea de Cercetare-Dezvoltare pentru Cultura Plantelor pe Nisipuri Dăbuleni \\ ${ }^{\star}$ Correspondence author. E-mail:milicadima@yahoo.com
}

Keywords: herbicides, sandy soils, peanuts.

\begin{abstract}
Peanut culture is very sensitive to weeds. Therefore, controlling the weeds is a very important link in the technology of growing peanuts on sandy soils. The researches on cultivation of peanuts has highlighted the possibility of controlling the weeds in peanut crops with the help of herbicides, being one of the most effective methods in controlling the weeds. Postemergence herbicides with Fusilade Forte 150EC 1.5 I/ ha + Corum + adjuvant Dash HC 1.25 I/ ha, had a good efficacy in controlling the dicotyledonous weeds.

The lowest degree of weeding at harvest under the influence of herbicides (15.4\%) compared to control 2 (cultivated), was recorded by spraying the peanut crop with Dual Gold 960EC 1.5 I/ ha + Fusilade Forte 150EC 1.5 I/ ha + Corum + Dash HC adjuvant 1.25 I/ ha.
\end{abstract}

\section{INTRODUCTION}

Using of fertilizers and water for irrigations on the psamosoils in the south of Oltenia offers favourable conditions of growth and development for cultivated plants, but also for weeds.

The high degree of weeding on sandy soils is determined by the fact that weed seeds retain their germination capacity easily and for a long time, due to good aeration and lower soil moisture.

The peanut culture is very sensitive to weeds. Therefore, controlling the weeds is a very important link in the technology of growing peanuts on sandy soils. In many countries, weed competition can cause production losses in peanut crops (Goldson 1967, Ishag 1971, Carson 1976, Rethinam et al. 1976, Drennan \& Jennings 1977, Lagoke et al. 1981, Yadav et al. 1984, Hamada et al. 1988). Competition between plants and weeds varies on account of growing conditions (Smartt 1964, Schiller et al. 1976), cultivated genotype (Brown 1965), applied fertilizers (Ashrif 1967) and existing spectrum of weeds (Hamada 1988). The results on controlling weeds for peanuts show that weeding in the first four to eight weeks after sowing is essential to prevent production losses (Dumas \& Ausan 1978). Also, reducing the sowing distance between rows could contribute to lower weed competition on crops (Buchanan \& Hauser 1980).

The researches on the peanut crop by Milica Dima 2004, highlighted the possibility of weed control in peanut crops with the help of herbicides, being one of the most effective methods of weed control. 
The use of herbicides amplifies the coefficient of capitalization by cultivated plants of vegetation factors: light, nutrition space, fertilizing elements, irrigation (Snake 1987, Pintilie et al. 1972).

The chemical control of weeds creates favourable premises for a completed mechanization of agricultural crops, while facilitating the increase of the efficiency of some agro-phytotechnical measures and the cultivation parameters for them (Şarpe et al. 1981).

The effective control of weeds for peanuts is generally achieved through the use of a herbicide program that consists in a preplant incorporation or preemergence treatment, followed by a postemergence treatment.

Proper identification of weeds is essential before deciding on a controllig of weeds program that includes the purchase of herbicides.

\section{MATERIAL AND METHODS}

In order to establish a broad-spectrum strategy to control monocotyledonous and dicotyledonous weeds in peanut cultivation, in the period of 2019-2021, 5 herbicides in different combinations and doses were studied.

The experiment was placed in the field using the randomized block method.

The experimental variants were: V1- control 1(uncultivated), V2- control 2(cultivated), V3- Dual Gold 960 EC, V4-Stomp Aqua, V5- Dual Gold 960 EC + Fusilade Forte 150 EC, V6- Stomp Aqua + Fusilade Forte 150 EC, V7- Dual Gold $960 \mathrm{EC}+$ Fusilade Forte $150 \mathrm{EC}+$ Corum + adjuvant Dash HC, V8- Stomp Aqua + Fusilade Forte $150 \mathrm{EC}+$ Corum + adjuvant Dash HC, V9- Dual Gold $960 \mathrm{EC}+$ Fusilade Forte $150 \mathrm{EC}+$ Benta $480 \mathrm{SL}, \mathrm{V} 10$ - Stomp Aqua + Fusilade Forte $150 \mathrm{EC}$ + Benta 480 SL.

During the vegetation period, observations and experimental determinations were made regarding:

- herbicide selectivity by grades on the EWRS scale (grade 1-selective, grade 9-non-selective);

- the effectiveness of herbicides on the degree of weeding through grades on the EWRS scale (grade 1-very good efficacy, grade 9-very poor efficacy); groups of weeds;

- degree of weeding at harvest: by EWRS notes (1-9) and gravimetric by

- some elements of productivity: no. of pods per plant, production of pods per ha.

Peanut pod production was calculated at STAS humidity of $9 \%$.

The interpretation of research results was done by the method of analysis of variance.

\section{RESULTS AND DISCUSSIONS}

The bad weeds on sandy soils are Cynodon dactylon and Sorghum halepense, species of monocotyledonous weeds that are common in peanut cultivation due to the high degree of infestation of sandy soils, but also a dicotyledonous species, Ambrosia artemisiifolia. 
Results of selective herbicides applied to peanut crop

\begin{tabular}{|c|c|c|c|c|}
\hline No. & Variant & Dose $(1 /$ ha $)$ & Epoch of application & $\begin{array}{c}\text { EWRS } \\
\text { Note }(1-9)\end{array}$ \\
\hline 1 & Control 1 (Uncultivated)) & & & \\
\hline 2 & Control 2 (Cultivated) & & & \\
\hline 3 & Dual Gold 960EC & 1,5 & preemergence & 2 \\
\hline 4 & Stomp aqua & 4 & preemergence & 1 \\
\hline \multirow[t]{2}{*}{5} & Dual Gold960EC & 1,5 & preemergence & \multirow[b]{2}{*}{1} \\
\hline & Fusilade & 1,5 & postemergence 1 & \\
\hline \multirow[t]{2}{*}{6} & Stomp aqua & 4 & preemergence & \multirow[b]{2}{*}{1} \\
\hline & Fusilade Forte 150EC & 1,5 & postemergence 1 & \\
\hline \multirow[t]{3}{*}{7} & Dual Gold 960EC & 1,5 & preemergence & \multirow[b]{3}{*}{2} \\
\hline & Fusilade Forte 150EC & 1,5 & postemergence 1 & \\
\hline & Corum+adjuvant Dash HC & 1,25 & postemergence1 & \\
\hline \multirow[t]{3}{*}{8} & Stomp Aqua & 4 & preemergence & \multirow[b]{2}{*}{2} \\
\hline & Fusilade Forte 150EC & 1,5 & postemergence 1 & \\
\hline & Corum+adjuvant Dash HC & 1,25 & postemergence 1 & \\
\hline \multirow[t]{3}{*}{9} & Dual Gold 960EC & 1,5 & preemergence & \multirow{3}{*}{2} \\
\hline & Fusilade Forte 150EC & 1,5 & postemergence 1 & \\
\hline & Benta $480 \mathrm{SL}$ & 1,25 & postemergence 1 & \\
\hline \multirow[t]{3}{*}{10} & Stomp Aqua & 4 & preemergence & \multirow{3}{*}{2} \\
\hline & Fusilade Forte 150EC & 1,5 & postemergence 1 & \\
\hline & Benta $480 \mathrm{SL}$ & 1,25 & postemergence 1 & \\
\hline
\end{tabular}

The results on the selectivity of the herbicides applied to the peanut crop showed that all the herbicides applied were selective for the peanut plants.

In the control of monocotyledonous weeds, the best results were obtained by using the combination of Dual Gold 960EC 1.5 I/ ha + Fusilade Forte 150EC 1.5 I / ha + Benta 480 SL 1.25 I / ha (Table 2).

In terms of the weight of weeds per group, a total quantity of weeds of 11390 $\mathrm{kg} / \mathrm{ha}$ is observed in the nonherbicide and untreated variant (control 1), and in the mechanically plowed variant (control 2) an amount of $6840 \mathrm{~kg} /$ ha annual dicotyledons and $2879 \mathrm{~kg} /$ annual monocotyledons. Compared to this variant, the best control of annual dicotyledonous weeds was achieved when the combination of herbicides Dual Gold 960EC applied preemergent + Fusilade Forte 150EC 1.5I / ha + Corum + Dash HC adjuvant $1.25 \mathrm{I} /$ ha applied postemergent $1(650 \mathrm{~kg} /$ ha annual dicotyledonous weeds). The smallest amount of weeds was obtained in the variant where the combination Stomp Aqua 4 I / ha + Fusilade Forte $150 \mathrm{EC} 1.5 \mathrm{I} / \mathrm{ha}+$ Corum + Dash HC adjuvant $1.25 \mathrm{I} / \mathrm{ha}$ (2555 kg / ha weeds).

The number of pods per plant differs depending on the herbicide variants, indirectly correlating with the degree of weeding.

Compared to the unroasted control 1 , in which 18.5 mature pods per plant were registered, the effectiveness of all herbicide variants is noticed, in which the number of pods per plant was between 22.6-49.6 pods per plant. The best results regarding the number of pods per plant were obtained by herbicide cultivation with Stomp Aqua $4 \mathrm{I}$ / ha + Fusilade Forte 150EC 1.5 I / ha + Corum + adjuvant Dash HC 1.25 I / ha, followed by the variant herbicide with Dual Gold 960EC 1.5 I / ha + Fusilade Forte 150EC 1.5 I/ ha + Corum + adjuvant Dash HC $1.25 \mathrm{I} /$ ha. 
Analyzing the production results obtained under the influence of herbicide( Table 3), a close correlation is highlighted between them and the value of the productivity elements. The variants with the best results regarding weed control presented maximum values in terms of production level.

Compared to the untreated control, in which a production of $373 \mathrm{~kg} / \mathrm{ha}$ was obtained, all herbicidal variants achieved production increases between 279-1199 $\mathrm{kg} / \mathrm{ha}$.

The production of all herbicide variants was higher than that obtained at the plowed control three times, the best results being obtained by herbicide cultivation with Stomp aqua 4I / ha + Fusilade 1.5I / ha + Corum + Dash HC adjuvant HC 1.25 I / ha, a situation in which there was a significant increase in production compared to the hoe.

The results obtained for the non-herbicide variant, with a low production of $373 \mathrm{~kg} / \mathrm{ha}$ of pods, highlight the importance of herbicides and maintenance works applied to the cultivation of peanuts on irrigated psamosols.

\section{CONCLUSIONS}

All tested herbicides on peanuts showed selectivity for the plant. Postemergence herbicide I with Fusilade Forte 150EC 1.5 I/ ha + Corum + adjuvant Dash $\mathrm{HC} 1.25 \mathrm{I} / \mathrm{ha}$, had a good efficacy in controlling the dicotyledonous weeds.

The lowest degree of weeding at harvest under the influence of herbicides (15.4\%) compared to control 2 (cultivated), was recorded by spraying the peanut crop with Dual Gold 960EC 1.5 I/ ha + Fusilade Forte 150EC 1.5 I/ ha + Corum + Dash HC adjuvant $1.25 \mathrm{I} / \mathrm{ha}$.

The lowest degree of weeding leads to the normal development of plant metabolism on account to a different way of the generative organs, especially in terms of ensuring good cultural hygiene and the availability of a large amount of water for productive consumption of peanuts.

The non-herbicide and the non-mechanical cultivation work led to a very significant decrease of the obtained production $(373-424 \mathrm{~kg} / \mathrm{ha})$.

\section{REFERENCES}

Ashrif M.I. 1967. Effects of fertilizer, weeding and pre-emergence MCPB on groundnuts in the Gambia, PANS (C) 13: 207-214.

Brown P. 1965. A review of groundnut experiments in Malawi. Rhodesian Journal of Agricultural Research 3: 39-50.

Buchanan G.A. \& Hauser E.W. 1980. Influence of row spacing on competitiveness and yield of peanuts (Arachis hypogaea). Weed Science 28: 401-409.

Carson A.G. 1976. Weed competition and control in groundnuts (Arachis hypogaea L.). Ghana Journal of Agricultural Science 9: 169-173.

Dima M. 2004. Tehnologia de cultivare a arahidelor pe solurile nisipoase,în Tehnologii de cultivare a cerealelor, plantelor tehnice, plantelor furajere şi plantelor medicinale pe solurile nisipoase, Editura Sitech, Craiova.

Drennan D.S.H. \& E.A. Jennings 1977. Weed competition in irrigated cotton (Gossypium barbadense L.) and groundnut (Arachis hypogaea L.) in the Sudan Gezira. Weed Research 17: 3-9.

Dumas R.E. \& Ausan S. 1978. Research results and practical experiences regarding weed control in peanuts in Suriname. Proceedings Carribean Food Crops Society 15: 272-287. 
Goldson J.R. 1967. Weeding requirements of groundnuts in Western Kenya. East African Agricultural and Forestry Journal 32: 246-249.

Hamada A.A. 1988. Weed competition in irrigated groundnuts, variety Ashford, in the Rahad Scheme, Sudan. Beiträge zur Tropischen Landwirtschaft und Veterinärmedizin 26: 25-31.

Hamada A.A., Babiker E.A. \& Khalifa F.M. 1988. Effect of weeds, nitrogen and phosphorus fertilizers on pod yield and growth of groundnuts at Rahad (Sudan). Oléagineux 43: 379-382.

Ishag H.M. 1971. Weed control in irrigated groundnuts (Arachis hypogaea L.) in the Sudan Gezira. Journal of Agricultural Science (Cambridge) 77: 237-242.

Janssen B.H. \& Wienk J.F. 1990. Mechanized annual cropping on low fertility acid soils in the humid tropics. A case study of the Zanderij soils in Suriname. Wageningen Agricultural University Papers 90.5, 230 pp.

Lagoke S.T.O., Choudhary A.H. \& Tanko Y.M. 1981. Weed control in rainfed groundnut (Arachis hypogaea L.) in the Guinea savanna zone of Nigeria. Weed Research 21: 119-125.

Rethinam P., Selvaranga Raju G., Sankaran N. \& Morachan Y.B. 1976. Studies on crop-weed competition and chemical weed control in groundnut. Madras Agricultural Journal 63: 454-457.

Şarpe N. 1987- Combaterea integrată a buruienilor din culturile agricole, Editura Ceres, Bucureşti.

Şarpe N., Strejan Gh. 1981- Combaterea chimică a buruienilor din culturile de câmp, Editura Ceres, Bucureşti.

Schiller J.M., Prasart Dogkeaw \& Prasit Jina 1976. Weed control in rainfed peanut (Arachis hypogaea L.) production in Northern Thailand. Thai Journal of Agricultural Science 9: 51-65.

Smartt J. 1964. Factors influencing yield and quality of groundnuts in Northern Rhodesia. Empire Journal of Experimental Agriculture 32: 343-351.

Yadav S.K., Singh S.P. \& Bhan V.M. 1984. Crop-weed competition studies in groundnut (Arachis hypogaea L.). Journal of Agricultural Science (Cambridge) 103: 373-376. 


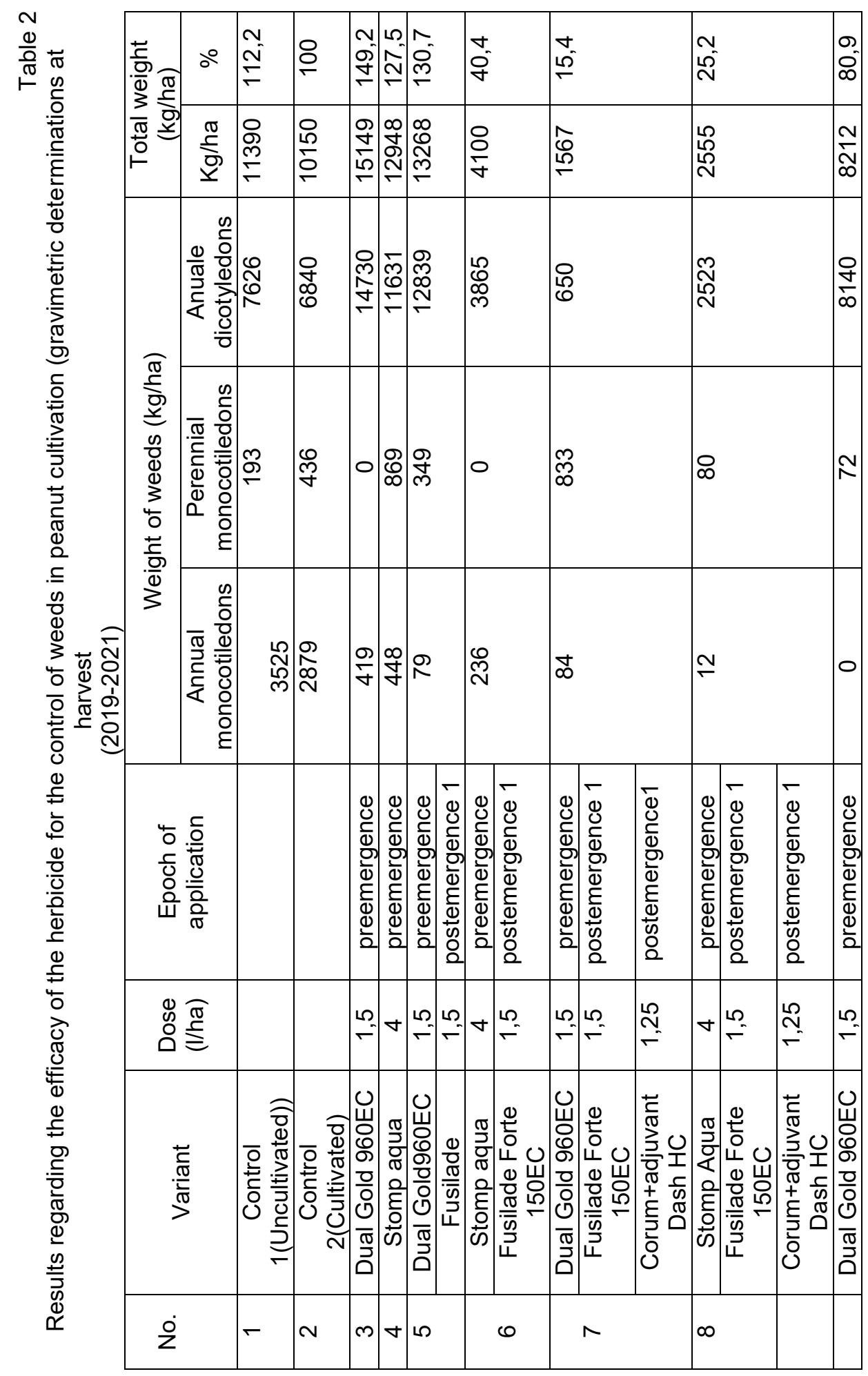



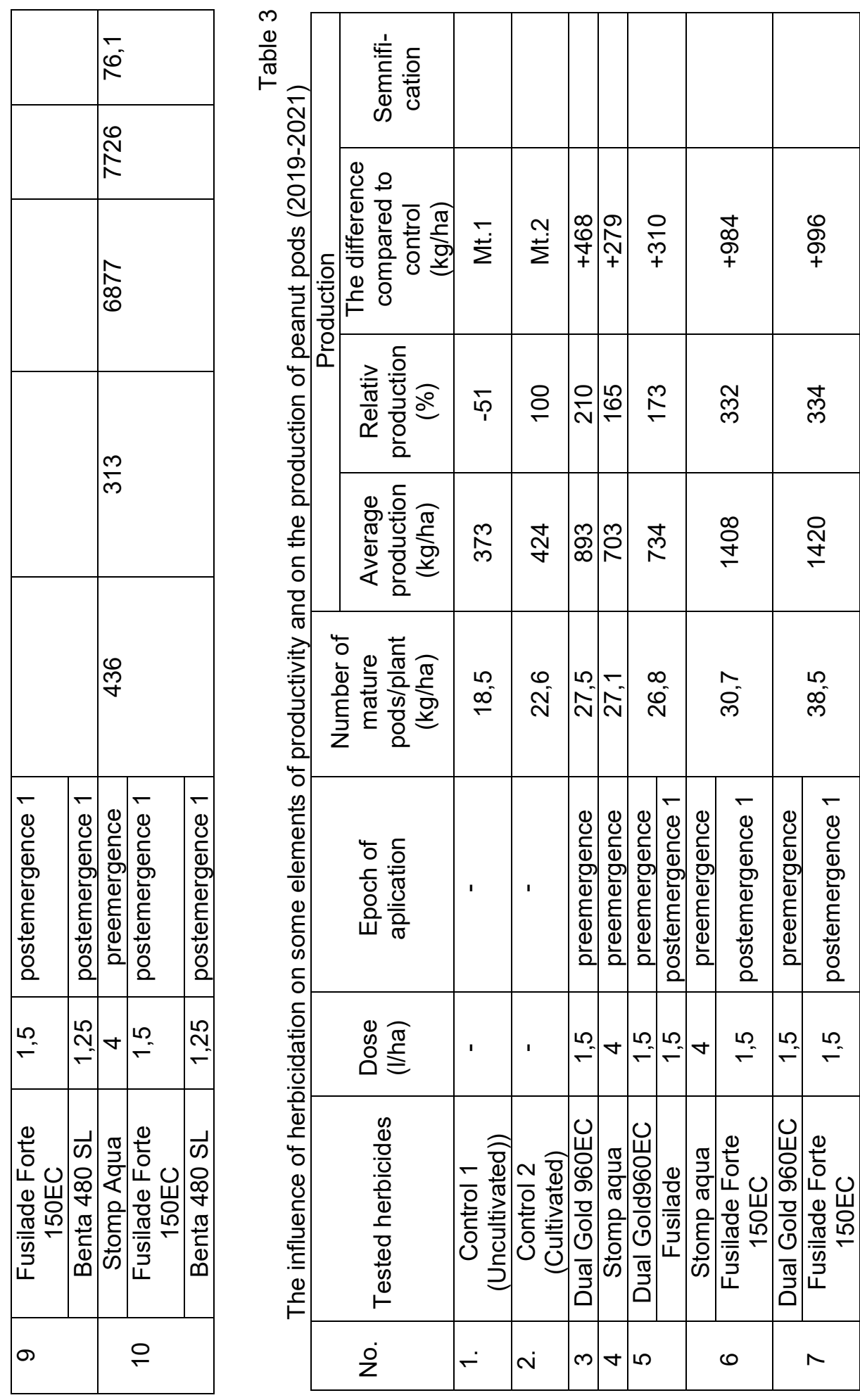


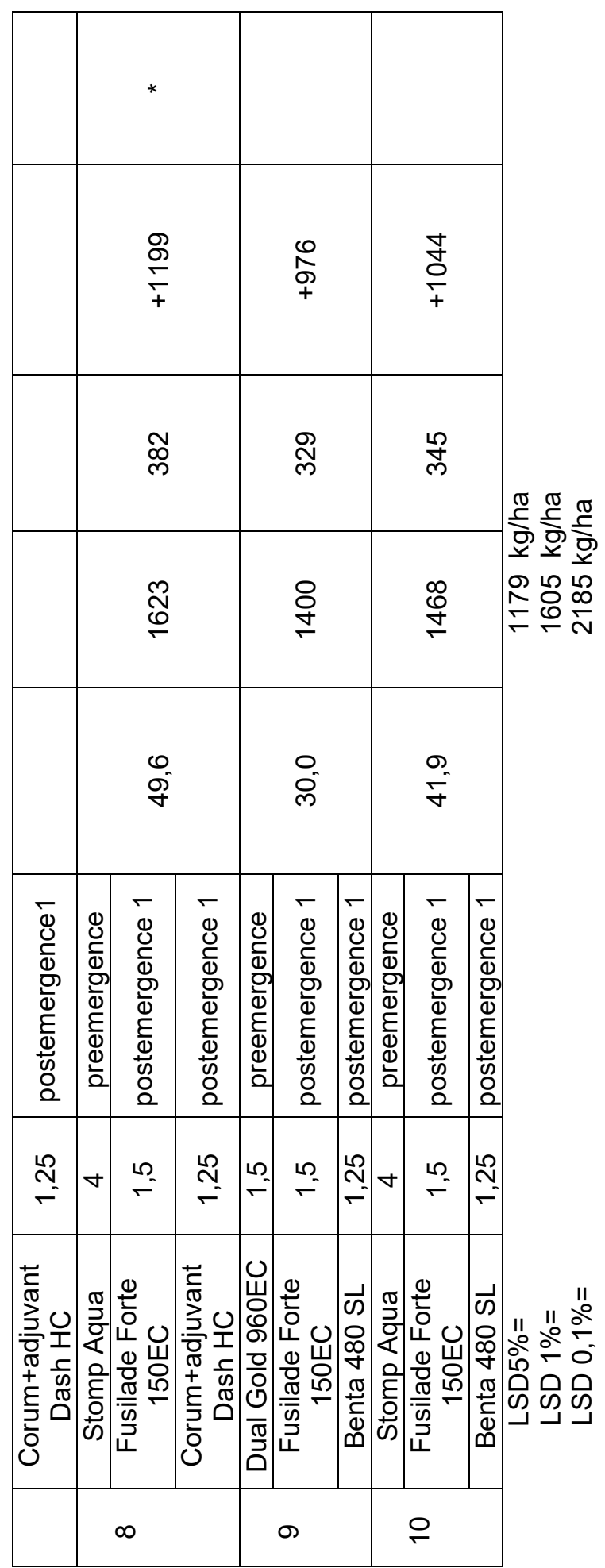

